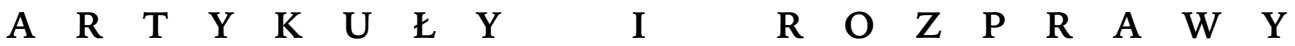

JÓZEF WRZESIŃSKI

\section{WIEDZA PROWADZĄCA DO DZIAŁANIA}

Przemówienie wygłoszone przez ojca Józefa Wrzesińskiego, założyciela Międzynarodowego Ruchu ATD Czwarty Świat, 3 grudnia 1980 r. w siedzibie

UNESCO w Paryżu z okazji otwarcia obrad Stałego Komitetu ds. Badań Ubóstwa i Wykluczenia Społecznego*

\section{WSTĘP}

Pragnę podziękować za to, że odpowiedzieliście Państwo na nasz apel i zechcieliście spotkać się $\mathrm{w}$ grudniu, miesiącu, w którym każdy z nas ma tyle obowiązków. Witając Was w siedzibie UNESCO uświadamiam sobie, że już od dwudziestu pięciu lat uczeni, badacze, specjaliści podzielają nadzieje i niepokoje Ruchu ATD Czwarty Świat. To ponad ćwierć wieku wiernego zaangażowania i wspólnej troski z Waszej strony i środowisk, które reprezentujecie.

Nasz Ruch w latach sześćdziesiątych założył własny Instytut Badawczy. Impulsem do jego powstania były kontakty z międzynarodową społecznością badaczy. Zaczęło się od więzów przyjaźni, które przerodziły się w regularną współpracę. W roku 1964 pojawiła się potrzeba stworzenia grupy, wspólnych rozmów i działań, które pozwoliłyby się wspierać, a jednocześnie wychodzić na zewnątrz.

${ }^{*}$ Tytuł francuskiego oryginału La pensée des plus pauvres dans une connaissance qui conduise au combat. Tekst ukazał się w przeglądzie „Revue Quart Monde” nr 140 w 1991 r.

Nieco inną wersję przemówienia, przetłumaczoną na język angielski, pt. Knowledge that Leads to Action, opublikowano w pracy zbiorowej Participatory Approaches to Attacking Extreme Poverty: Cases Studies Led by the International Movement ATD Fourth World pod redakcją Xaviera Godinota oraz Quentina Wodona, World Bank Working Paper, nr 77, Washington D.C. 2006. Autorami tego tłumaczenia są Alice Husson, Bruno Tardieu, Xavier Louveaux, Charles Sleeth oraz Charles Courtney. Także tę wersję brano pod uwagę przy tym tłumaczeniu. 
Dlatego też takie spotkanie jak dzisiaj, w obrębie Komitetu, nie jest niczym nowym dla historii Ruchu. Nowością jest jedynie jego stały charakter. To dopiero w 1979 r. ogłosiliśmy publicznie potrzebę stworzenia na forum międzynarodowym stałej grupy, która pełniłaby ważną funkcję w życiu społeczności narodowych i międzynarodowych.

Tego ranka nie chcę jednak mówić ani o historii Komitetu, ani o potrzebie jego stałego charakteru. O tym wszystkim dyskutowaliśmy w ramach Komitetu i składających się nań grup roboczych począwszy od 1979 r. Nasze podstawowe wspólne idee można znaleźć w sprawozdaniach Komitetu.

Chciałbym powiedzieć o roli Komitetu, jakiej dotychczas nikt nie spełniał w Ruchu (a wedle mojej najlepszej wiedzy także nigdzie na świecie). Chodzi mianowicie o zadanie, a wręcz obowiązek spoczywający na przedstawicielach świata nauki — zapewnienia wiedzy osób ubogich i wykluczonych należnego jej miejsca. Ten rodzaj wiedzy w szczególny sposób powinno się cenić, ponieważ jest to wiedza niezastąpiona, ma charakter wyjątkowy, jest wiedzą autonomiczną, a jednocześnie stanowi uzupełnienie innych rodzajów wiedzy o ubóstwie. Naszym obowiązkiem jest wspierać rozwój tego rodzaju wiedzy. Wiąże się z tym, jak możecie się domyślić, drugi obowiązek, a więc wspieranie i umacnianie wiedzy tych osób, które są blisko najuboższych i działają wraz z nimi.

Usłyszeliście już o dwóch komponentach naszej wiedzy o ubóstwie. Trzeci komponent stanowi Wasza wiedza - jako obserwatorów z zewnątrz. Kwestie te poruszamy nie pierwszy raz, jednak z uwagi na naszą wspólną pracę podczas bieżącej sesji i w przyszłości pozwolę sobie jeszcze raz doprecyzować kilka myśli Ruchu na ten temat. Przemyślenia te to owoc dwudziestu pięciu lat spotkań osób najuboższych i badaczy.

\section{WIEDZA AKADEMICKA O UBÓSTWIE JAKO WIEDZA KOMPLEMENTARNA}

Pytania, jakie zadaje sobie Ruch i jakie zadaje sobie również nasz Komitet, są - według mnie - następujące:

— Jakiej wiedzy potrzebują najubożsi?

— Jakiej wiedzy potrzebują grupy wolontariuszy? ${ }^{1}$

- Jakiej wiedzy potrzebuje nasze społeczeństwo i społeczność międzynarodowa, aby skutecznie walczyć z ubóstwem i wykluczeniem?

Bez wątpienia na podstawie własnych doświadczeń życiowych możemy stwierdzić, że każdy z nas przeszedł okres, w którym na to pytanie odpowiedziałby, że potrzebujemy wiedzy akademickiej. Wielu z nas sądziło, że jest to wiedza najbardziej użyteczna w działaniu, a więc taka, dzięki której będzie można wpływać na politykę i prawo, oraz że jest to taka wiedza, którą zdobywa

\footnotetext{
${ }^{1}$ Jest to nawiązanie do specyfiki działania Ruchu ATD. Na całym świecie w lokalnych zespołach pracują tzw. stali wolontariusze ATD, a więc osoby, które angażują się w działania Ruchu w pełnym wymiarze (przyp. tłum.).
} 
się na uniwersytecie albo w innej instytucji naukowej. Wiele oczekiwaliśmy od wiedzy, do której mają dostęp badacze, wykładowcy, naukowcy zajmujący się opisem rzeczywistości, ale jednocześnie żyjący w warunkach odmiennych od osób wykluczonych.

Wiedza akademicka była ceniona za metodologię, rygory poznawcze, obiektywizm. Poszukującym jasnych i merytorycznych rozwiązań złożonych problemów wyżej wymienione cechy miały gwarantować skuteczność i przejrzystość działań podejmowanych na rzecz najbiedniejszych w przeciwieństwie do stronniczości, której dopuszczali się politycy.

Uniwersytety były zatem postrzegane jako instytucje wiarygodne, miały być schronieniem dla tych, którzy nie chcieli ulec błędnym ideologiom, zarówno dominującym, jak i marginalnym. Na naszych uniwersytetach także w pewnym stopniu próbowaliśmy stosować takie podejście. Nie byliśmy w błędzie, ale i nie mieliśmy całkowicie racji.

Nie chodzi o to, że nauka, zwłaszcza nauki humanistyczne i społeczne nie są ani neutralne, ani obiektywne. Nie chodzi o powiązania nauki i metodologii badań $z$ ideologią. Zagadnienia te są ciekawe, ale moim zdaniem drugorzędne.

Sedno problemu stanowi fakt, że nie udało się nam dostrzec, iż wiedza uniwersytecka dotycząca ubóstwa i wykluczenia, tak jak zresztą każdy punkt widzenia, jest niepełna. Nie powiedzieliśmy jasno i nie jesteśmy jeszcze w stanie w pełni tego zrozumieć, że wiedza uniwersytecka może mieć jedynie charakter pośredni i informacyjny. Brakuje jej bezpośredniego zetknięcia z rzeczywistością, a tym samym nie może mobilizować i inspirować do działania.

Wielu z nas przeżyło rozczarowanie, gdy jakieś badanie nie dało rezultatów. Być może nie dość uwagi poświęciliśmy temu, że badania akademickie w ścisłym znaczeniu prowadzą do abstrakcji, do obrazu rzeczywistości obserwowanej z zewnątrz, wyrażonej językiem pozbawionym barw, uczuć i tego wszystkiego, co pobudza ludzi do działania na rzecz innych.

W ramach kompleksowej wiedzy na temat ubóstwa i wykluczenia społecznego, mającej za zadanie dostarczać informacji i prowadzić do działania, wiedza akademicka nie stanie się niczym więcej niż tylko jednym z jej komponentów, i to komponentem informacyjnym, „bez życia”, jeśli można tak powiedzieć, dopóki nie uwzględni się dwóch pozostałych elementów. Te dwa pozostałe to:

- wiedza, którą najubożsi i wykluczeni uzyskują na podstawie ich bezpośredniego doświadczenia rzeczywistości ubóstwa oraz rzeczywistości narzucanej im przez otaczający ich świat,

- wiedza osób, które działają wśród doświadczających ubóstwa i wykluczenia społecznego oraz pracują z nimi.

Podobnie jak całe społeczeństwo, uniwersytety także uległy złudzeniu nadrzędności wiedzy akademickiej, której świat potrzebuje, by walczyć z biedą. A kiedy najbardziej wnikliwe badania i analizy zniknęly w szufladach polityków i urzędników, uznaliśmy, że stało się tak z powodów politycznych. To prawda, ale nie uwzględniono tego, że problem stanowią nie tylko poli- 
tycy, ale także nasze badania, które nie potrafiły zachęcić polityków do działania.

Środowisko akademickie nie dostrzegło, iż niemożność bezpośredniego przełożenia ich wiedzy na działania polityczne może być przypisana temu, że jest to wiedza o charakterze dyrektywnym, ale nie mająca siły przekonywania i że te brakujące elementy wiedzy powinny pochodzić nie od badaczy, ale od osób ubogich i od tych, którzy z nimi pracują.

\section{BEZ WOLNOŚCI MYŚLENIA NIE MA POROZUMIENIA}

Oczywiście, nie wszyscy badacze pomijali dwa pozostałe komponenty wiedzy, a więc wiedzę pochodzącą od ubogich oraz od tych, którzy z nimi pracują i działaja. Jednakże, i tu tkwi sedno sprawy, komponenty te nie były postrzegane jako autonomiczne, o twórczym charakterze. Badacze szybko przekształcili tę wiedzę w obiekt swoich własnych badań: była ona dla nich źródłem informacji, które mogli wykorzystać do własnych celów, a nie równorzędnym projektem badawczym. Niekiedy wpisywali je w kontekst swoich własnych analiz jako zewnętrzni obserwatorzy życia ubogich i podejmowanych przez nich działań. Przywłaszczali więc sobie cudzą wiedzę, oddzielając ją od jej pierwotnego celu. Co więcej, bardzo często badacze ci nieświadomie lub mimowolnie znieksztalcali lub paraliżowali myśl swoich rozmówców. Działo się tak dlatego, że nie uznawali jej samodzielności i kierowali się tokiem własnego myślenia. Traktowali swoich respondentów jako źródło informacji, a nie jako osoby myślące niezależnie.

Jeżeli chodzi o sposób komunikowania się z biednymi, to wieloletnie doświadczenia uczą nas, że nawet tzw. metoda uczestnicząca praktykowana przez antropologów oraz etnologów niesie ze sobą ryzyko przywłaszczenia, zniekształcenia, a nawet unicestwienia myśli ubogich. A dzieje się tak dlatego, że obserwacjom tym przypisuje się cel, który jest zewnętrzny w stosunku do sytuacji życiowej ubogich, sytuacji, której oni sami ani nie wybrali, ani nie określiliby jej tak jak badacze. W istocie nie jest to więc obserwacja uczestnicząca, gdyż refleksje badaczy $z$ jednej strony i osób poddawanych obserwacji z drugiej mają zupełnie różne cele.

Nie chodzi tutaj o wybór niewłaściwej metodologii, ale raczej o samą sytuację życiową. Tylko przez zmianę sytuacji życiowej można znaleźć rozwiązanie problemu. Co więcej, nawet obserwacja uczestnicząca, która nie wywierałyby negatywnego wpływu na myślenie grupy o określonych kompetencjach i kulturze, niesie ze sobą ryzyko zniekształcenia myśli najbiedniejszych, którzy nie mają równie wysokich kompetencji.

Podobne trudności występują w przypadkach współpracy badaczy i praktyków. Trudności tego typu były wielokrotnie poddawane analizie. Na przykład mówi się, że grupom wolontariuszy nie udaje się współpracować z badaczami, ponieważ nie widzą $w$ tym sensu i są negatywnie nastawieni do nich oraz ich 
braku zrozumienia dla realiów życia codziennego i jego nieprzewidywalności. Mówi się też, że współpraca jest nieefektywna, ponieważ praktykom brakuje umiejętności logicznego rozumowania i że w swoich działaniach kierują się raczej intuicją i wrażeniami niż racjonalną analizą.

Być może w powyższych uzasadnieniach jest trochę prawdy, ale wydaje się, że nie sięgają one sedna. Podstawowym problemem jest to, że jeżeli praktycy mają wnieść istotny wkład $\mathrm{w}$ badania, muszą być traktowani nie tylko jako źródło informacji, ale jako osoby myślące, które własnymi sposobami dążą do uzyskania wiedzy zgodnej ze swoimi celami.

Tutaj znów obawiam się, że nawet badacze nauk społecznych analizujący działania i ich skutki mogą wyciągać błędne wnioski. Czyż nie jest tak, że pojawiają się oni, gdy kości zostały rzucone, po fakcie próbując zrozumieć sytuację całkowicie dla nich obcą? Stają twarzą w twarz z sytuacją, która jest inna od wszystkiego, co znają; stykają się z destabilizacją, o której mają niewielkie pojęcie. Zrozumienie i uchwycenie dynamiki analizowanej sytuacji nie jest możliwe dopóty, dopóki nie doświadczy się samemu, jak kruche i niepewne są podstawy, na których próbuje się opierać działanie wśród osób najbiedniejszych. Działanie to można zrozumieć jedynie $\mathrm{w}$ takim stopniu, $\mathrm{w}$ jakim uczestniczyło się W rozwoju myśli danej grupy praktyków i przyjęło przyświecające im cele.

Chciałbym zaznaczyć, że celem moim nie jest wytknięcie słabości badań akademickich wynikających z problemów komunikacyjnych. Zamierzałem przede wszystkim pokazać, że badania te, niezależnie od ich jakości, nie mogą dać wiedzy wyczerpującej. Badacz sam nie jest w stanie dostarczyć pełnej wiedzy, która pozwoliłaby na skuteczną walkę z nędzą. Wróćmy jeszcze na moment do dwóch pozostałych źródeł wiedzy. Mogą one stanowić istotne uzupełnienie wiedzy uniwersyteckiej dopiero wtedy, kiedy traktowane są jako autonomiczne oraz mające własne cele.

\section{TAJEMNICZY OGRÓD NAJUBOŻSZYCH}

Zastanówmy się przez chwilę, jaka jest wiedza i sposób myślenia ludzi Czwartego Świata ${ }^{2}$. Muszą radzić sobie myślowo nie tylko ze swoją sytuacją życiową, ale i ze światem, który więzi ich w ubóstwie i w którym panuje tak duży kontrast między tym, jak powinni być traktowani najubożsi, a tym, jak są traktowani.

Nie trzeba przypominać, że myślenie i wiedza to rodzaj aktywności, do której zdolny jest każdy człowiek, niezależnie od posiadanych zdolności i doświad-

2 Od początku istnienia Ruchu szukano takiego określenia osób doświadczających ubóstwa, które nie powielałoby negatywnych stereotypów, ale wzmacniało ich poczucie godności i tożsamości. „Czwarty Świat” jest nawiązaniem do mało znanego epizodu z czasów rewolucji francuskiej, kiedy to arystokrata Dufourny de Villiers w dziele Kroniki czwartego stanu upominał się o prawa grupy najbiedniejszych obywateli (przyp. tłum.). 
czenia. Każdy stara się poznać i zrozumieć rzeczywistość po to, aby zrealizować własny cel. Ponieważ myślenie nakierowane jest na cel, każda myśl może stać się aktem osobistego wyzwolenia. Opierając się na swoich doświadczeniach w różnych obszarach ubóstwa Ruch ATD Czwarty Świat może zaświadczyć, że każda osoba i każda grupa nosi w sobie taki potencjał, niezależnie od tego jak skromne ma zdolności myślenia i analizy. Każdy człowiek i każda grupa poszukuje zrozumienia siebie i swojej sytuacji po to, aby panować nad swoim przeznaczeniem, zamiast poddawać mu się z lękiem.

Ci, którzy sądzą, że ludzie mogą zostać całkowicie spauperyzowani, zredukowani do apatii, tak że nie myślą, że zrzekają się swojej niezależności, a ich życie sprowadza się do przetrwania, popełniają poważny błąd. Ignorują oni strategie samoobrony, które budują najubożsi, aby wydostać się spod wpływu osób, od których są zależni. Ubodzy chronią swoją egzystencję, ukrywają ją starannie, jakby za zasłoną, i stwarzają iluzje przeznaczone dla zewnętrznych obserwatorów. Badacze często pomijają rozpaczliwe wysiłki, jakie podejmują osoby ubogie, które wciąż pytają same siebie: „Kimże ja w końcu jestem?”, lub nieraz mówią: „Traktują mnie jak psa, jak nic nie wartego tchórza, idiotę, jak przedmiot”, „Czy rzeczywiście jestem nic nie wartym tchórzem?”. A także usiłują przebić się przez fałszywe oskarżenia i etykietki, jakie im się przypisuje, powtarzając: „Ależ ja nie jestem psem. Nie jestem idiotą, za którego mnie uważają. Dużo wiem na temat spraw, których oni i tak nigdy nie zrozumieją".

Nadchodzi taki moment, kiedy mimo wątpliwości co do własnej wartości takie przekonanie staje się niezwykle silne. I osoba wypowiadająca takie słowa, wyniszczona i udręczona życiem, ma rację. Na pewno wie więcej niż ktokolwiek mógłby zrozumieć lub sobie wyobrazić. Jej wiedza nie jest uporządkowana, ale jest wiedzą o życiu w pogardzie i wykluczeniu. Obejmuje ona wszystko to, co jej się przydarza, cierpienie, jakie przeżywa, ale i walkę z przeciwnościami i nadzieję na lepszą przyszłość. Jest także wiedzą o otaczającym ją świecie, o pewnych postawach wobec biednych, których świadomi są tylko sami biedni. Nawet najlepszym badaczom trudno wszystko to sobie wyobrazić. Nie są w stanie sformułować właściwych hipotez i pytań. Muszą stawić czemuś czoło, ale nie mają potrzebnych ku temu narzędzi. Jest to, można powiedzieć, tajemniczy ogród najuboższych. Wstęp jest dozwolony tylko dla tych, którzy zmienią swoją sytuację życiową i będą w stanie zdobyć zaufanie ubogich, tak aby odważyli się oni mówić - otworzą się na ich zrozumienie. Inaczej trudno sobie wyobrazić, w jaki sposób ktoś, kto pochodzi z innego świata i czyje myślenie zostało przez ten świat ukształtowane, mógłby zostać wpuszczony do tajemniczego ogrodu. Jest jeszcze coś. Osoby z zewnątrz nie mają do tego prawa.

Tak naprawdę nikt nie ma prawa, nawet $\mathrm{w}$ imię nauki, tłumić cudzych dążeń do wewnętrznego wyzwolenia, nawet jeżeli są one nieporadne, ale jednak niesłabnące. Żaden badacz nie ma prawa wykorzystywać do własnych celów starań osób najbiedniejszych. Musimy stale pamiętać, że wykorzystywanie najbied- 
niejszych jako obiektów badawczych, zamiast skłaniania ich do samodzielnego myślenia, jest aktem zniewolenia. Tym bardziej że ich myślenie jest zawsze poszukiwaniem historii i tożsamości, i to oni sami mają bezpośredni dostęp do tego, co stanowi sedno odpowiedzi. Zadają sobie o wiele więcej pytań na temat swojej historii oraz tożsamości niż na temat potrzeb czy nawet praw, ponieważ intuicyjnie uważają, że dzięki zadawaniu sobie takich pytań znajdą drogę do wolności.

Nie chcę przez to powiedzieć, że mówienie osobom żyjącym w ubóstwie o ich prawach lub pytanie ich o potrzeby zawsze jest błędem. Może być jednak dla nich wyzwalające tylko o tyle, o ile dialog odbywa się w kontekście ich tożsamości historycznej, rozumianej tak jak oni ją rozumieją, a jedyna wiedza, jaka jest dla nich pomocna, to taka, która traktuje osoby ubogie podmiotowo i daje im narzędzia do realizacji ich praw i potrzeb.

Do tej pory było raczej na odwrót. Przez cały okres tzw. wojny z biedą (war on poverty ${ }^{3}$ ) w Stanach Zjednoczonych nie powstała ani jedna praca badawcza poświęcona życiu tych, o których w tamtych czasach mówiono hardcore poor („zatwardziali biedacy”). Nie mówiąc o tym, że nie było również badań, które powstałyby we współpracy z samymi „zatwardziałymi biedakami".

Odnosi się to także do Wielkiej Brytanii, a więc kraju, który stawia się za wzór, ponieważ od lat systematycznie są tam prowadzone badania nad stanem ubóstwa, nawet w okresie dobrobytu w latach sześćdziesiątych. Ale nawet tam kwestia tożsamości nie jest uwzględniana. Osoby żyjące w ubóstwie są postrzegane wyłącznie przez pryzmat ich potrzeb i braków. Tendencję tę można częściowo przypisać szacunkowi, jaki badacze mają dla najuboższych, i ich trosce o nienadawanie im etykietek, a tym samym nieprzyczynianie się do segregacji. Czy jest to jednak podejście słuszne, jeśli weźmiemy pod uwagę, że tożsamość historyczna jest źródłem siły i godności i że to tożsamość niesie ważne przesłanie dla całego społeczeństwa?

To rodziny Czwartego Świata nauczyły nas, że mówić do nich wyłącznie o ich potrzebach lub w kontekście wskaźników społecznych, które opisują tę grupę, nie pomagając im jednocześnie lepiej zrozumieć ich własnej historii i tego, co ich jednoczy, to kolejny sposób ich zniewolenia. To same rodziny zwracają się do Ruchu z prośbą, która nie brzmi „Wytłumaczcie nam”, ale raczej „Pomóżcie nam myśleć”. Coraz więcej rodzin mówi: „Musimy myśleć, bo inaczej nikt nas nie zrozumie".

3 Określenia tego po raz pierwszy użył prezydent Lyndon B. Johnson w stosunku do ustawy z 1964 r. dotyczącej pomocy społecznej. Ustawa, której był inicjatorem, miała dać odpowiedź na wysoką stopę ubóstwa w społeczeństwie amerykańskim. Istotnym elementem programu było zwiększenie nakładów z budżetu federalnego na pomoc społeczną oraz zintensyfikowanie roli państwa (przyp. tłum). 


\section{JAK WSPIERAĆ DĄŻENIA CZWARTEGO ŚWIATA DO POZNANIA}

Liczymy na Was - jako na naukowców - że będziecie dokładnie badać i analizować to, czego Czwarty Świat nauczył nas o swoim prawie do posiadania własnej myśli i do uznania swojej autonomicznej wiedzy. To od nas i od Was zależy, czy nauczymy się wspierać wysiłek podjęcia refleksji przez osoby najuboższe. Nawet jeżeli rodziny Czwartego Świata pokazały wyraźnie, że chcą myśleć samodzielnie, to jednocześnie nigdy nie twierdziły, że nie potrzebują pomocy. Wręcz przeciwnie - gdziekolwiek trafiają nasze ekipy, słyszymy tę samą prośbę: „Wy, którzy nauczyliście się myśleć, nauczcie nas, jak to robić". Czy to w Gwatemali, Szwajcarii, Nowym Jorku, Bangkoku, czy w ubogich dzielnicach Londynu najbiedniejsi potrzebują obecności, ale nie „ekspertów od myślenia" (tych widzieli już zbyt wielu), ale kompetentnych, inteligentnych mężczyzn i kobiet, którzy mogą nauczyć ich, jak myśleć, a jednocześnie nie będą im narzucać swojego sposobu myślenia.

Czy posiadamy do tego odpowiednie narzędzia oraz metodologię? Nie mam co do tego pewności. Pojawili się już pionierzy. Ale ostrożna analiza eksperymentów prowadzonych w kilku krajach pozostawia pewne wątpliwości. Wydaje się, że projekty realizowane w duchu „uświadomienia” najuboższych w Ameryce Łacińskiej, Indiach czy nawet w Europie pomijają osoby ubogie. Niezależnie od tego, czy chodzi o wioski indiańskie w Kolumbii, chatki nietykalnych w Indiach, slumsy w Kalkucie czy najbiedniejsze osiedla w Portugalii, najbiedniejsi mieszkańcy bywają marginalizowani nawet $\mathrm{w}$ tego typu projektach.

Być może należy sobie postawić pytanie, czy projekty te nie narzucają mieszkańcom Dalekiego Wschodu zachodniego języka i zachodnich koncepcji. Czy ludzie ci użyliby wyrażeń brzmiących tak bardzo znajomo dla zachodniego ucha: „próba sił”, „zniewolenie człowieka przez człowieka”, „walka klasowa”? Czy nie woleliby mówić językiem swojej własnej cywilizacji?

Uważamy, że nasz Komitet ma coś do powiedzenia w odpowiedzi na pytanie, jakie warunki należy spełnić, aby zagwarantować rzeczywiste wsparcie dla rozwoju myśli i wiedzy najuboższych. Nasz Komitet powinien i może ukazywać znaczenie myśli najuboższych nie tylko w kontekście ich udziału w walce przeciwko wykluczeniu, ale i po to by włączyć w tę walkę całe społeczeństwo. Powraca tutaj echem pytanie, które zadaliśmy sobie na początku: jakiej wiedzy potrzebujemy wszyscy?

To miałem na myśli mówiąc, że bez wiedzy, którą mają osoby żyjące w ubóstwie i którą powinny móc rozwijać, wiedza akademicka niesie ze sobą ryzyko pozostania wiedzą fragmentaryczną i bezduszną, a tym samym nie będzie mogła pobudzić ludzi do działania i walki. Nie wgłębiając się w filozofię czy w psychologię, podajmy powody, dla których - według doświadczenia Ruchu tylko głos osób żyjących w ubóstwie może pobudzać do działania, a wszystkie inne rodzaje wiedzy mają charakter pomocniczy. 
Po pierwsze, w świecie pełnym szlachetnych inicjatyw i apeli o niewielkim znaczeniu nie udaje się zachęcić ludzi do trwałych działań. Wiedza cząstkowa, która nie pokazuje sedna sprawy, a więc cierpienia i nadziei osób wykluczonych, nie przemówi do serc ludzi i nie zainspiruje ich do zaangażowania się. Nasz Ruch, złożony ze zwykłych obywateli, osiągnął cele, które przy skromnych zasobach wydawały się niewyobrażalne, właśnie dlatego, że nigdy nie przestał ukazywać, jakie skutki niesie ze sobą skrajne ubóstwo.

Jedynie najubożsi znają jego straszliwe konsekwencje. Zaznali niesprawiedliwości, naruszeń praw człowieka, cierpienia związanego z wykluczeniem. To oni wiedzą, co musi się zmienić w sercach, umysłach obywateli i funkcjonowaniu demokracji. Wnioski z badań akademickich są zaledwie słabym odbiciem ich przeżyć, spłaszczoną formą przekazu.

Po drugie, kiedy spojrzymy na przesłanie rodzin Czwartego Świata jako na jedną całość, to uderza fakt, iż trafia ono w sedno, zawiera w sobie wszystko, co potrzebujemy wiedzieć o tym, jakie jest i jakie powinno być społeczeństwo. Niektórzy z was przypominają sobie nasze starania o rozpowszechnianie tego przesłania w latach sześćdziesiątych na forum Międzynarodowego Towarzystwa Socjologicznego. W latach siedemdziesiątych z kolei realizowaliśmy pilotażowy projekt „Europejski program badań i przeciwdziałania ubóstwu”. Nasz Ruch zaproponował narzędzia i warunki, które najuboższym z najuboższych w Unii Europejskiej mają umożliwić mówienie własnym głosem zamiast głosem socjologów. Mimo że nasza propozycja przypadła na okres bezpośrednich wyborów do Parlamentu Europejskiego, eksperci rządowi nie wykazali nią zainteresowania.

Praktyka pokazuje, że Ruch zyskuje nowych członków tylko wtedy, gdy oddaje głos rodzinom Czwartego Świata i pozwala im wyrażać ich własną prawdę. Jesteśmy jedynie organizacją pozarządową, a jeżeli udaje się nam trwać i rozwijać się, to czyż nie dzieje się tak dlatego, że przesłanie najuboższych ma tak wielką siłę przekonywania, gdyż w swojej istocie jest nie do odrzucenia?

Pozwolę sobie ponownie powtórzyć, że dla Ruchu najważniejsza jest walka o to, aby najubożsi mogli mówić do swoich współobywateli własnym głosem, a nie w tłumaczeniu na język badaczy. Czy nie powinniśmy uznać tego faktu z pokorą? Udaje nam się zyskiwać poparcie polityczne, ponieważ ludzie zdają sobie sprawę, że nasz Ruch umożliwia osobom żyjącym w ubóstwie zabranie głosu i stwarza im warunki, by zostali wysłuchani.

Nasz Komitet przynajmniej część czasu powinien przeznaczyć na wspieranie najuboższych $\mathrm{w}$ ich refleksji, co jest niezbędnym warunkiem, aby zrozumieć wykluczenie, w tym także zabieranie głosu przez najuboższych, gdyż to ono mobilizuje współobywateli do działania. Kwestia ta zostanie poruszona podczas debaty „Czwarty Świat w Afryce”. Temat ten ponownie będzie podjęty w czasie dyskusji na temat znaczenia europejskiej polityki dotyczącej ubóstwa w państwach członkowskich. Wreszcie po raz trzeci pojawi się w tekście, który 
przedstawi profesor Jona Rosenfeld i wprowadzi nas w problematykę partnerstwa w walce $z$ wykluczeniem.

Pytanie, które sobie postawiliśmy, stanowi punkt odniesienia dla wszystkich dyskusji zaplanowanych podczas dzisiejszej sesji, ale jednocześnie wskazuje ramy istnienia Komitetu i sposobu planowania jego celów długoterminowych. To dlatego należało je zadać już na samym początku konferencji.

\section{DZIAŁANIA, KTÓRE SAME W SOBIE STANOWIĄ MYŚL I PRZESŁANIE}

Czy dotychczasowe uwagi o konieczności zachowania niezależnego charakteru wiedzy pozyskiwanej przez praktyków wymagają jeszcze uzupełnienia? To, co powiedzieliśmy o prawach Czwartego Świata, odnosi się także w sposób oczywisty i do osób pracujących $z$ biednymi. Ich zadaniem jest rozwijanie szczególnej wiedzy, która musi opierać się na działaniach, doświadczanych przeciwnościach i niepewności, uwzględniać reakcje i zmiany, a także nowe idee i projekty, które powstają $\mathrm{w}$ wyniku ich obecności i pracy. Myślenie to powinno być wspierane przez kompetentne osoby $z$ zewnątrz, ale jednocześnie rozwijać się w sposób swobodny i być nakierowane na własne cele.

Osoby odpowiedzialne za działania potrzebują takiego myślenia, żeby spełnić spoczywające na nich obowiązki. Oczywiste jest, że rodzinom Czwartego Świata potrzebna jest obecność grup wolontariuszy zdolnych do samodzielnego myślenia.

Także działacze, tak samo jak osoby najbiedniejsze, mogą stać się przedmiotem badań akademickich. Podejmowane są również próby ewaluacji ich działań. Chociaż istnieją na ten temat interesujące badania, to odnosimy się do nich $z$ rezerwą. Niepokoi nas fakt, że badania te, będąc próbą uchwycenia istoty działań od zewnątrz, nie mogą przecież zastąpić wiedzy, którą przynoszą działania o sobie i dla siebie. Jest to obszar, który pozostaje niemal niedostępny dla specjalistów z zakresu nauk społecznych, dla tych samych powodów, dla których rzeczywistość doświadczana przez najbiedniejszych pozostaje poza ich zasięgiem.

Wiedza praktyków, jako wspomniany wcześniej trzeci rodzaj wiedzy, jest niezbędnym komponentem wiedzy twórczej i kompleksowej na temat ubóstwa. Społeczeństwo potrzebuje tego rodzaju wiedzy, aby działać. Potrzebne są mu przykłady zaangażowanych w działanie obywateli. Powinno ono słuchać działaczy tak samo, jak powinno słuchać naukowców.

Czyż poza świadectwem ubogich to właśnie nie świadectwo wolontariuszy pobudza ludzi do działania? Usłyszane historie mogą wzbudzić w innych pragnienie i odwagę potrzebne do tego, aby to oni z kolei podjęli działanie.

I tutaj badacze mogą wyświadczyć nieocenioną przysługę działaczom, okazując wsparcie i uznanie dla tego rodzaju wiedzy, zamiast wykorzystywać ją do własnych celów. 


\section{KOMITET GOTOWY DO DZIAEANIA}

Można powiedzieć, że to osoby najuboższe uświadamiają nam, jak ważna jest rola badaczy uniwersyteckich. Chodzi o przywrócenie należnego miejsca wiedzy ubogich, wsparcie oraz rozwój nowego podejścia do wiedzy na temat ubóstwa, a wreszcie o współpracę między badaczami, praktykami oraz osobami doświadczającymi ubóstwa. Komitet może mieć w tym względzie istotny wkład.

Badacze mogą działać w innych ważnych obszarach, jednak praca, jaką podejmuje Komitet, wydaje się w tym momencie najpilniejsza, najpotrzebniejsza oraz najbardziej innowacyjna. Pod warunkiem, że będziemy postrzegać Komitet, w który wkładamy tyle energii i z którym wiążemy tak duże nadzieje, jako źródło inspiracji do działania.

Ttumaczenie Magdalena Macińska

\section{KNOWLEDGE THAT LEADS TO ACTION}

Sum mary

The speech of Father Józef Wrzesiński, delivered in 1980 during a sitting of the International Conference on Poverty and Social Exclusion of UNESCO set forward a programme for action. The author drew attention to the unappreciated knowledge that the poor themselves have on poverty on the basis of their own direct experiences and emphasises the role of the knowledge about poverty of the people working amongst those who experience its effects. Without these two types of information on the topic, academic knowledge would be incomplete and inadequate, since it cannot form the basis of a programme of activity. In these three types of knowledge and their roles, Father Wrzesinski refers to the experience of the International Movement ATD Fourth World.

\section{Key words/słowa kluczowe}

poverty / ubóstwo; knowledge based on experience / wiedza oparta na doświadczeniu; knowledge of the poorest and excluded / wiedza osób najuboższych i wykluczonych; knowledge of activists and volunteers / wiedza działaczy i wolontariuszy; ATD Fourth World / ATD Czwarty Świat; the Fourth World families / rodziny Czwartego Świata 